\title{
DEVELOPING STUDENTS' SELECT COMPETENCES DURING TECHNOLOGY, PHYSICS AND MATHEMATICS LESSONS AT BASIC SCHOOLS
}

\author{
Jozef PAVELKA, Prešovská univerzita v Prešove, Slovenská republika
}

Přijato: 25. 5. 2016 / Akceptováno: 2. 8. 2016

Typ článku: Výskumný článok

DOI: $10.5507 /$ jtie.2016.026

Abstrakt: This paper presents research results of the research project and is focused on the possibilities of the development of select key compentences of the students during technology, physics, and mathematics lessons through the use of interactive whiteboard at the select basic schools. The main aim of the project was to verify the application of proposed didactic materials and methods in educational practise. These research results were further used at the university textbook focusing on the implementation of interactive board into teaching of select courses at basic schools as well as on the introduction of the course module of Methodology of information technologies into the pre-service teacher training programme at the university.

Key words: basic school, key skills, interactive whiteboard.

\section{ROZVÍJANIE VYBRANÝCH KOMPETENCIÍ ŽIAKOV NA HODINÁCH TECHNIKY, FYZIKY A MATEMATIKY V ZÁKLADNEJ ŠKOLE}

Abstract: Prispevok prezentuje celkové výsledky výskumu, ktorý bol zameraný na skúmanie doteraz netradičných možností rozvoja vybraných klúčových kompetencii žiakov na hodinách techniky, fyziky a matematiky vo vybranej vzorke základných škôl na Slovensku s využitím interaktívnej tabule. Ciel’om realizácie výskumu bolo v školskej praxi overit' použitelnost' navrhnutých metodických materiálov a postupov, ktoré následne boli použité na vypracovanie vysokoškolskej učebnice zameranej na implementáciu interaktívnej tabule do výučby vybraných predmetov $v$ ZŚ a na vypracovanie a zavedenie Metodiky IT do výučby vysokoškolských študentov - budúcich učitel'ov s príslušným predmetovým zameranim.

Klúčové slová: základná škola, klúčové kompetencie, interaktívna tabul'a.

\footnotetext{
*Autor pro korespondenci: jozef.pavelka@unipo.sk
} 


\section{1 Úvod}

Prvou oblast'ou, ktorá prijatím školského zákona č. 245/2008 Z. z. o výchove a vzdelávaní na Slovensku nastolila kvalitatívne novú ciel'ovú požiadavku na výchovu a vzdelávanie žiakov je oblast' rozvíjania kl’účových kompetencií žiakov. Dovtedy, ale i v súčasnosti sa rozvoju klúčových kompetencií žiakov venovali samotní učitelia skôr individuálne a sporadicky.

Druhou oblast'ou, ktorá si vyžaduje intenzívnu pozornost' je oblast' využívania interaktívnych tabúl' (IT) vo výučbe, nakol'ko je známe, že množstvo škôl IT vlastní, no ich účinné využívanie učitel'mi vo výučbe je rovnako skôr individuálne a sporadické.

Systémový prístup školských štátnych orgánov $\mathrm{k}$ skúmaniu a metodickému usmerňovaniu škôl $\mathrm{v}$ oblasti využívania interaktívnych tabúl' vo výučbe a k rozvoju kl'účových kompetencií žiakov na nižšom stupni stredného vzdelávania (ZŠ) v SR doposial' nebol realizovaný.

Uvedené viedlo kolektív pedagógov z FHPV PU v Prešove, FPV UMB v B. Bystrici a PF UKF v Nitre k riešeniu projektu GA MŠ VV a Š SR KEGA č. 015PU-4/2013 „Metodika implementácie interaktívnej tabule pri vzdelávaní ku kompetenciám v príprave učitelov techniky, fyziky a matematiky pre nižšie sekundárne vzdelávanie“. K riešeniu projektu sme pristúpili z týchto podstatných dôvodov:

- $\quad$ na Slovensku sa systémovému prístupu k rozvoju a skúmaniu kl'účových kompetencií žiakov v učebných predmetoch technika, fyzika a matematika $(\mathrm{T}-\mathrm{F}-\mathrm{M}) \mathrm{v}$ ZŠ doposial' temer nik nezaoberal,

- na fakultách pripravujúci učitel'ov pre uvedené učebné predmety sa doposial' príprava so zameraním na rozvoj kl'účových kompetencií žiakov s využitím interaktívnej tabule v Z ̌̌ nerealizovala,

- $\quad$ z dostupných výsledkov prieskumov a osobných zistení vyplýva, že interaktívne tabule, ktoré ZŠ získali v rámci rôznych projektov, alebo ktoré zakúpili, sú počas výučby hodín $\mathrm{T}-\mathrm{F}$ - M využívané minimálne, resp. nie sú využívané vôbec.

Ciel'om príspevku je sprístupnit' vedeckej a odbornej komunite pôsobiacej v oblasti didaktík vybraných prírodovedných a technických predmetov prístupy kolektívu riešitel'ov projektu z Katedry F - M - T FHPV PU v Prešove, Katedry T a T FPV UMB v B. Bystrici a Katedry T a IT PF UKF v Nitre, ktoré v období rokov 2013 až 2015 použili pri riešení a skúmaní osobitého vedeckého problému, akým je využívanie interaktívneho prostredia s akcentom na IT vo výučbe T - F - M a s ciel'om zároveň vytvárat' podmienky a prispiet' k rozvíjaniu vybraných kl’účových kompetencií žiakov 5. až 9. ročníka ZŠ. Hlavným ciel'om bolo vypracovanie a overenie Metodiky IT pre prípravu učitel'ov nižšieho stredného vzdelávania v ZŠ na vysokých školách a jej zavedenie do výučby.

\section{Projekt experimentálneho výskumu}

Aby bolo možné do výučby a prípravy budúcich učitel'ov $\mathrm{T}-\mathrm{F}$ - M pre nižší stupeň stredného vzdelávania zaviest' aj modul obsahovo zameraný na rozvoj schopností študentov vytvárat' také modely a stratégie výučby, ktoré s využitím interaktívnej tabule napomáhajú vytvárat' podmienky a tým prispievat' k rozvoju vybraných kl’účových kompetencií žiakov, bolo najskôr potrebné uskutočnit' štúdium odbornej literatúry a publikácií zameraných za predmetný problém. Na základe analýzy odborných prameňov a zistení bola navrhnutá 
prvotná východisková štruktúra a rámcový obsah teoretickej a praktickej časti budúceho diela, t.j. Metodiky IT. Aby bolo možné prijat' záver, že celá, ale najmä praktická čast' metodiky je odborne, didakticky i funkčne vhodne a správne vypracovaná, t. j. modely a stratégie vyučovacích hodín, predvádzacie zošity pre IT a pracovné listy žiakov sú v školskej praxi plne použitel’né a prinášajú očakávaný efekt, bol vo vybraných školách počas výučby jednotlivých učebných predmetov realizovaný experimentálny výskum. Dokial' sme pristúpil k realizácii samotného výskumu, bolo o. i. potrebné realizovat' nasledujúce dôležité aktivity: získavanie, štúdium a spracovanie literatúry so zámerom získania podkladov na vytvorenie Metodiky IT; vykonanie čiastkových prieskumov, ktoré boli zamerané na zistenie druhov a softvérov IT, ktoré sa $v$ ZŠ používajú a na zistenie ochoty škôl spolupracovat' pri realizácii výskumných aktivít; na základe zistení, že v ZŠ a na VŠ sa používa viac druhov IT a viac druhov softvérov, bol riešený závažný problém, akým bola potreba zabezpečit' kompatibilitu softvéru napr. Smart Notebook s inými druhmi softvérov, ktoré sú v súvislosti s IT v ZŠ používané; individuálny tréning zameraný na bezproblémové ovládanie a prácu so softvérom a IT a na tvorbu predvádzacích zošitov pre žiakov; v závere šk. r. 2013/2014 a od začiatku šk. r. 2014/2015 bola medzi výskumníkmi a základnými školami vedená intenzívna komunikácia zameraná na skúmanie časového rozloženia učív $\mathrm{v}$ tematických výchovno-vzdelávacích plánoch $\mathrm{T}-\mathrm{F}$ - M, ktorej ciel'om bolo vytypovat' ZŠ, ročníky a témy vyučovacích hodín, počas ktorých sa experimentálna výučba a výskum v ZŠ bude realizovat'; tvorba návrhov modelov vyučovacích hodín, tvorba predvádzacích zošitov pre vybrané témy vyučovania $\mathrm{T}-\mathrm{F}-\mathrm{M}$ vo vybraných ročníkoch 5 . až 9 . Z Š́, vývoj meracích nástrojov a ich konzultovanie vo vybraných ZŠ a s partnerom v zahraničí; vypracovanie prvotnej koncepcie a stratégie realizácie výskumných aktivít; analýza a výber vhodných metód na realizáciu výskumu; realizácia výskumných aktivít; spracovanie a vyhodnotenie výsledkov čiastkových výsledkov výskumov a výskumných aktivít ako celku; vypracovanie vzdelávacieho modulu Metodika IT a vysokoškolskej učebnice.

\section{Ciele výskumu}

Hlavným ciel'om výskumu bolo overit', či navrhnuté modely a stratégie výučby učebných predmetov $\mathrm{T}-\mathrm{F}-\mathrm{M}$, aplikované počas výučby vo vybraných ročníkoch $Z \mathrm{~S}$ a témach vyučovacích hodín $\mathrm{v}$ spojení s využitím IT, vytvárajú podmienky a prispievajú $\mathrm{k}$ rozvíjaniu vybraných klúčových kompetencií žiakov.

Čiastkovými ciel'mi výskumu bolo overenie vhodnosti a správnosti vypracovaných modelov, stratégií výučby a učebných pomôcok (predvádzacích zošitov a pracovných listov žiakov) a overenie funkčnosti vypracovaných meracích nástrojov (pozorovacích hárkov).

\section{Hypotézy výskumu}

Základnou a vzhl’adom na dosial' neprebádanú problematiku, pracovnou hypotézou výskumu bola hlavná hypotéza:

Predpokladáme, že navrhnuté modely a stratégie výučby aplikované vo výučbe učebných predmetov $\mathrm{T}-\mathrm{F}-\mathrm{M}$ počas experimentálnej výučby vo vybraných ročníkoch 5 . až 9 . Z a vybraných témach vyučovacích hodín v spojení s využitím IT vytvoria podmienky, ktoré prispejú k rozvíjaniu vybraných kl’účových kompetencií žiakov. 
Zámerom bolo zistit' účinok nezávisle premennej - vyučovanie s použitím IT a pracovných listov žiakov (príčina) - na závisle premennú - rozvoj vybraných klúčových kompetencií žiakov (dôsledok).

Ked’že v zmysle hlavného ciel'a nám išlo najmä o potvrdenie vhodnosti a správnosti vypracovaných metodických materiálov $\mathrm{v}$ súvislosti $\mathrm{s}$ rozvojom vybraných klúčových kompetencií žiakov a nie o podrobné skúmanie rozvoja výkonov žiakov v kognitívnej oblasti a o skúmanie kvantitatívnej i kvalitatívnej miery vplyvu metodických materiálov na rozvoj klúčových kompetencií žiakov, pre potreby výskumu neboli stanovené d’alšie pracovné hypotézy.

\section{Predmet a vzorka výskumu}

Predmetom výskumu bol rozvoj vybraných klúčcvých kompetencií vybraných skupín žiakov vyvolaných vplyvom metodík realizovaných v rámci výučby $\mathrm{T}-\mathrm{F}$ - M s využitím IT. Objektom výskumu bola vybraná vzorka žiakov 5. až 9. ročníkov vybraných ZŠ v prešovskom, nitrianskom a banskobystrickom regióne (tabul'ka 3 ). $\mathrm{K}$ výberu vzoriek čiastkových výskumov pristúpil výskumný tím zohl'adňujúc reálne jestvujúce podmienky v ZŠ. Z hladiska výberu vzorky výskumu výskumníci pre výber uplatnili stratifikovaný zámerný výber. Informácie o konkrétnych základných školách, $\mathrm{v}$ ktorých sa experimentálna výučba realizovala, s uvedením konkrétnych ročníkov nižšieho stredného vzdelávania a početnosti vzoriek výskumu uvádza tabul'ka 3.

\section{Kl'účové kompetencie}

Z hladiska vymedzenia pojmu kl'účové kompetencie sme sa priklonili $\mathrm{k}$ definícii Tureka (2002), t.j. klúčové kompetencie sú „najdôležitejšie z množiny kompetencií. Sú vhodné na riešenie celého radu väčšinou nepredvídatel'ných problémov, ktoré umožňujú jedincovi úspešne sa vyrovnat's rýchlymi zmenami v práci, v osobnom i spoločenskom živote“. Autor navrhuje tento systém klúčových kompetencií: informačné, učebné, kognitívne, interpersonálne, komunikačné, personálne.

Nakol'ko problematika klúčových kompetencií človeka je vel’mi rozsiahla a vnútorne široká, prijatý bol východiskový záver, t.j. že výber vybraných kl’účových kompetencií žiakov z množiny kompetencií uskutoční každý výskumník samostatne, pričom k výberu pristúpi na základe týchto kritérií:

- výber bude vychádzat' z vymedzenej skupiny predmetových kl'účových kompetencií, ktoré vymedzujú špecifické kl’účové prírodovedné a technické kompetencie žiaka nižšieho stupňa stredného vzdelávania,

- špecifické ciele vyučovacích hodín sa počas experimentálnej výučby majú dosiahnut',

- obsah a charakter učiva má byt' počas experimentálnej výučby realizovaný,

- rozsah výučby - zakaždým 1 vyučovacia hodina vo vybranom ročníku 5. až 9 .,

- dodržanie špecifik učebného predmetu T-F - M,

- počet vybraných klúčových kompetencií, ktoré budú pozorovatel'mi vo vybraných skupinách žiakov sledované a zaznamenávané $v$ rámci jednej vyučovacej hodiny a počas experimentálnej výučby bude maximálne do 15 .

Príklad vybraných klúčových kompetencií žiaka $\mathrm{v}$ učebnom predmete technika pre čiastkový výskum realizovaný Pavelkom uvádza tabul'ka 1 . 


\begin{tabular}{|l|l|}
\hline Kategória kl'účovej kompetencie & Vybraná kl'účová kompetencia \\
\hline Interpersonálna & pracovat' v tíme \\
\hline Informačná & interpersonálne vzt'ahy \\
\hline & $\begin{array}{l}\text { informácie kriticky hodnotit' a pou } \\
\text { riešenie problému }\end{array}$ \\
\hline Komunikačná & vyjadrovat' sa graficky \\
\hline & čítat's porozumením \\
\hline & vyjadrovat' sa ústne \\
\hline Personálna & vyjadrovat' sa písomne \\
\hline & kontrolovat' svoje správanie \\
\hline & zodpovednost' za výsledok \\
\hline & čestnost' a zodpovednost' \\
\hline Učebná & sebahodnotenie \\
\hline & motivovat' seba aj druhých \\
\hline Kognitívna & riešit' problém \\
\hline & kritické myslenie a hodnotenie \\
\hline
\end{tabular}

Tab. č. 1:Vybrané klúčové kompetencie žiaka - technika

Teoretické rozpracovanie problematiky klúčových kompetencií s vymedzením základných pojmov a konkrétne informácie o výbere kl’účových kompetencií, ktorých výskyt v rámci jednotlivých pozorovaní bol sledovaný a pozorovatel'mi zaznamenávaný, obsahuje publikácia Pavelku a Kozíka (2015).

\section{Použité metódy}

Z hladiska klasifikácie druhov pedagogického výskumu sa riešitelia projektu rozhodli a v školskej praxi realizovali aplikovaný experimentálny výskum krátkodobý, skupinový, heuristický výskum. Na základe analýzy metód vedeckého výskumu a analýzy reálnych možností získat' objektívne výsledky výskumov na overenie stanovenej hypotézy a tiež zhodnotenia možností výskumného tímu a ZŠ, tím sa pre experimentálne účely rozhodol použit' metódu pozorovania, lebo napr. podl'a definície Gavoru „Pozorovanie znamená sledovanie činnosti l'udí, záznam alebo popis tejto činnosti a jej hodnotenie. Predmetom pozorovania sú osoby, ale i predmety, s ktorými tieto osoby pracujú a napokon i prostredie, $v$ ktorom sa činnost' uskutočňuje“, t.j. táto metóda vyhovuje najviac potrebám výskumu (Gavora, 1996). Ako pomocná metóda bola zvolená metóda rozhovoru. Vedomí si skutočnosti, že pozorovanie je d'alej možné delit' podl'a viacerých kritérií, vzhl'adom na ciele a zámery výskumu, možnosti výskumníkov a tiež na reálne možnosti realizácie pozorovania $\mathrm{v}$ školách, bolo rozhodnuté $\mathrm{v}$ rámci čiastkových výskumov uplatnit' štruktúrované pozorovanie priame a krátkodobé, skupinové a čiastkové. Při štruktúrovanom pozorovaní bola všetkými pozorovatel'mi (členovia výskumného tímu) uplatňovaná vel'mi dôležitá podmienka na zachovanie prirodzenosti pozorovanej situácie. Pozorovatelia žiadnym spôsobom nezasahovali do pedagogických situácií, vhodné miesto pozorovatel'a zaujali tesne pred začiatkom vyučovacej hodiny, učebňu opúšţali po odchode žiakov z učebne, pozorovanie vykonávali diskrétne. Pozorované skupiny žiakov (zakaždým dve náhodne vybrané dvojice žiakov) nevedeli, že sú objektom pozorovania, aby nedošlo k vplyvu 
na ich správanie. Počas pozorovaní sa pozorovatelia zameriavali najmä na výskyt a zaznamenávanie javov, ktoré boli predmetom pozorovaní. Pozorovacie hárky boli vyhotovené podl'a učebných predmetov $\mathrm{T}-\mathrm{F}-\mathrm{M}$, podl'a jednotlivých tém vyučovania a v súlade $\mathrm{s}$ úlohami predvádzacích zošitov a pracovných listov pre žiakov. Do pozorovacieho hárku bol pozorovatel'mi zaznamenávaný výskyt javov zapísaním „áno“ (alebo „,+“) alebo zapísaním „nie“ (alebo ,-,,) v riadku tabul'ky s príslušným javom v rámci jednotlivých etáp vyučovacej hodiny. $\mathrm{V}$ závere pozorovacieho hárku pozorovatel' po skončení pozorovania v sumárnej tabul'ke zhotovil súčty výskytov (frekvenciu výskytu) jednotlivých pozorovaných javov. „, Aby pozorovatelia mohli určovat' aj intenzitu jednotlivých pozorovaných javov, aby pozorovanie bolo presnejšie a aby sa výsledky pozorovania dali aj štatisticky spracovat' (najmä testovat' hypotézy výskumu), je potrebné použivat' aj tzv. posudzovacie škály" (Švec, 1998; Kerlinger, 1972; Gavora, 2008; Turek, 1998). S ciel'om zabezpečit' čo najvyššiu mieru zhodnosti a jednotnosti výsledkov pozorovaní u všetkých výskumníkov bola prijatá posudzovacia škála tak, aby boli jednotlivé pozorované vlastnosti (javy) postrehované (zaznamenávané) pomocou zatial' dvoch stupňov, ktoré zodpovedajú ich krajnej intenzite. Príklad časti posudzovacej škály uvádza tabul'ka 2 . Za potrebné považujeme uviest', že za účelom zvýšenia validity a reliability pozorovania posúdenie posudzovacej škály a pozorovacích hárkov skupinou expertov vzhl’adom na objektívne možnosti výskumníkov nebolo možné uskutočnit'. V snahe zvýšit' validitu a reliabilitu výskumných nástrojov boli jednotlivé nástroje pripomienkované $\mathrm{v}$ rámci výskumného tímu. Vzájomný zácvik pozorovatel'ov $\mathrm{v}$ rámci jednotlivých subkolektívov sa uskutočnil na každom z pracovísk participujúcich na výskume. Metóda rozhovoru bola v rámci výskumu použitá na skúmanie názorov a postojov učitel'ov podiel'ajúcich sa na výučbe realizovanej novými stratégiami výučby s využitím IT.

\begin{tabular}{|l|l|l|}
\hline \multicolumn{2}{|c|}{ Posudzovacia škála k vybraným kl'účovým kompetenciám - učebný predmet technika } \\
\hline Kategória (jav - kompetencia) & \multicolumn{1}{c|}{ Prejavy (správanie sa) } \\
\hline $\begin{array}{l}\text { Interpersonálna - pracovat' } \\
\text { v tíme }\end{array}$ & pracuje - neradí sa & radia sa obaja vo dvojici \\
\hline $\begin{array}{l}\text { Informačná - informácie } \\
\text { kriticky hodnotit' a použit' } \\
\text { na riešenie problému }\end{array}$ & $\begin{array}{l}\text { číta a rieši úlohu samostatne } \\
\text { (čiastočne, neúspešne) }\end{array}$ & $\begin{array}{l}\text { informácie kriticky hodnotí } \\
\text { a sám úlohu úspešne rieši }\end{array}$ \\
\hline $\begin{array}{l}\text { Informačná - vyjadrovat' sa } \\
\text { graficky }\end{array}$ & $\begin{array}{l}\text { náčrt el. schémy je nejasný, } \\
\text { nesprávny a neúhl'adný }\end{array}$ & $\begin{array}{l}\text { náčrt je čitatel'ný, správny } \\
\text { a úhl'adný }\end{array}$ \\
\hline $\begin{array}{l}\text { Komunikačná - čítat' } \\
\text { s porozumením }\end{array}$ & $\begin{array}{l}\text { text číta a chápe - rieši úlohu } \\
\text { (čiastočne, neúspešne) }\end{array}$ & $\begin{array}{l}\text { text pochopil a úlohu úspešne } \\
\text { rieši }\end{array}$ \\
\hline $\begin{array}{l}\text { Komunikačná - vyjadrovat' } \\
\text { sa ústne }\end{array}$ & $\begin{array}{l}\text { vyjadruje sa tažkopádne } \\
\text { a nesúvisle }\end{array}$ & $\begin{array}{l}\text { vyjadruje sa bez väčších } \\
\text { problémov }\end{array}$ \\
\hline
\end{tabular}

Tab. č. 2: Priklad posudzovacej škály vybraných klúčových kompetencií 


\section{Harmonogram výskumu}

Na stanovenie harmonogramu realizácie čiastkových výskumov malo zásadný vplyv časové rozloženie učív v tematických výchovno-vzdelávacích plánoch $\mathrm{T}-\mathrm{F}-\mathrm{M} \mathrm{v}$ školskom roku. To nás viedlo $\mathrm{k}$ tomu, aby každý člen výskumného tímu vypracoval individuálny harmonogram realizácie vlastných čiastkových výskumných aktivít. Všetky čiastkové výskumy sa v ZŠ uskutočnili v období septembra 2014 až júna 2015.

\section{Priklad metodiky experimentálnej výučby}

Ako príklad navrhnutej a aplikovanej časti metodiky vo výučbe učebného predmetu technika uvádzame rámcový postup výučby, postup riešenia čiastkovej úlohy a práce žiakov na vybranej úlohe a spôsob vyhodnotenia úlohy.

Téma vyučovacej hodiny techniky: Schematické značky, jednoduchý elektrický obvod.

Postup výučby: Žiaci pracujú v náhodne zvolených dvojiciach, každý žiak má sadu 4 pracovných listov (PL), ktorých obsah je identický so stránkami predvádzacieho zošita interaktívnej tabule (IT). Učitel' postupne prezentuje jednotlivé stránky predvádzacieho zošita na IT a podl'a jeho pokynov žiaci úlohy v PL riešia. Následne, žiaci priamo na IT dopisujú údaje a slová, kreslia, premiestňujú obrázky atd’. a spoločne vyhodnocujú správnost' riešení žiakov.

Priklad úlohy: V tíme si prečítajte pomocné texty, porozmýšlajte, porad’te sa a správne názvy $\mathrm{z}$ ponuky prirad’te čiarami $\mathrm{k}$ jednotlivým druhom zobrazenia (stránka predvádzacieho zošita č. 5, úloha „a“).

Pozorované klúčové kompetencie (výskumníkom sledované len u náhodne vybraných dvoch skupín žiakov zaznamenávané do pozorovacieho hárku): Interpersonálna - pracovat'v tíme; Interpersonálna - harmonické vzt’ahy (kludná pracovná atmosféra); komunikačná - čitat s porozumením; kognitívna - kritické myslenie a hodnotenie informácií; Informačná informácie kriticky hodnotit' a použit' na riešenie problému

Úlohou žiakov bolo najskôr samostatne prečítat' si svoj krátky text (príloha k PL 1), potom spolupracovat's partnerom - porovnat' si v skupine texty, lebo text každého žiaka bol obsahom odlišný, spolupracovat' $\mathrm{v}$ kl’udnej atmosfére - poradit' sa k prečítaným textom a spoločne vo svojich PL 1 riešit' úlohu „a“. Úlohu žiak vyriešil správne len vtedy, ak čítal s porozumením - svoj text pochopil, ak sa poradil s partnerom a pochopil text partnera a na základe chápania textov a vzájomnej spolupráce čiarami správne pospájal obrázky s ponúknutými možnost’ami (názvy druhov schém) a do záverečného textu doplnil chýbajúce slová (napr. „technickým“, „elektrických schém“ a „technických výkresov“).

Priklad vyhodnotenia prvej časti vybranej úlohy „, “ " pracovného listu žiaka PL 1 (Klúčová kompetencia: Interpersonálna - pracovat'v tíme):

Z výsledkov pozorovaní práce skupín žiakov s PL 1 vyplýva:

- v ZŠ Važecká v Prešove v skupine dievčat došlo $\mathrm{k}$ intenzívnej spolupráci, v skupine chlapcov k spolupráci nedošlo,

- v ZŠ Májové námestie v Prešove je výsledok opačný, v skupine dievčat k spolupráci nedošlo, $\mathrm{k}$ intenzívnej spolupráci došlo $\mathrm{v}$ skupine chlapcov,

- v ZŠ Sibírska v Prešove v skupine dievčat došlo k intenzívnej spolupráci, v skupine

chlapcov k spolupráci nedošlo. 
Zo 6 pozorovaných skupín žiakov (spolu 12 žiakov) v 3 skupinách došlo k pozorovaniu javu, t.j. klúčcovej kompetencie „Interpersonálnej - pracovat’ v tíme“ a rovnako v 3 skupinách žiakov k pozorovaniu uvedeného javu nedošlo. Zistenie, že 50,00 \% žiakov v pozorovaných skupinách vzájomne nespolupracovalo umožňuje konštatovat', že formulácia a zaradenie úlohy v PL 1 „a“ má opodstatnenie v metodike výučby. Ked’že úloha vyžaduje vzájomnú spoluprácu, bez ktorej nie je možné úlohu riešit', vytvára podmienky a prispieva u žiakov $\mathrm{k}$ rozvíjaniu vybranej kl'účovej kompetencie.

Súbor vyhotovených predvádzacích zošitov, pracovných listov, metodík a stratégií výučby a konkrétne vyhodnotenie výsledkov práce žiakov na úlohách, ktoré obsahovali pracovné listy, obsahuje vysokoškolská učebnica Implementácia interaktívnej tabule vo výučbe techniky, fyziky a matematiky v základnej škole (Ďuriš - Pavelka a kol., 2015). Považujeme za potrebné uviest' aj tú skutočnost', že časový priestor stanovený obdobím výskumu a prebiehajúca výučba $\mathrm{v}$ školách (podla vopred školami schválených tematických výchovno-vzdelávacích plánov), neposkytovali výskumníkom možnosti realizovat' pilotáže zamerané na overenie správnosti a vhodnosti vypracovaných predvádzacích zošitov, pracovných listov pre žiakov a metodík a stratégií výučby priamo v školách. Výskumníci s ciel'om získat' názory a postoje kvalifikovaných odborníkov na vypracované materiály, konzultovali a pripomienkovali predmetné materiály tak navzájom, s učitel'mi techniky, fyziky a matematiky $\mathrm{z}$ rôznych ZŠ, ako aj s tými učitel’mi, ktorí v rámci experimentálnej výučby výučbu $v$ školách realizovali.

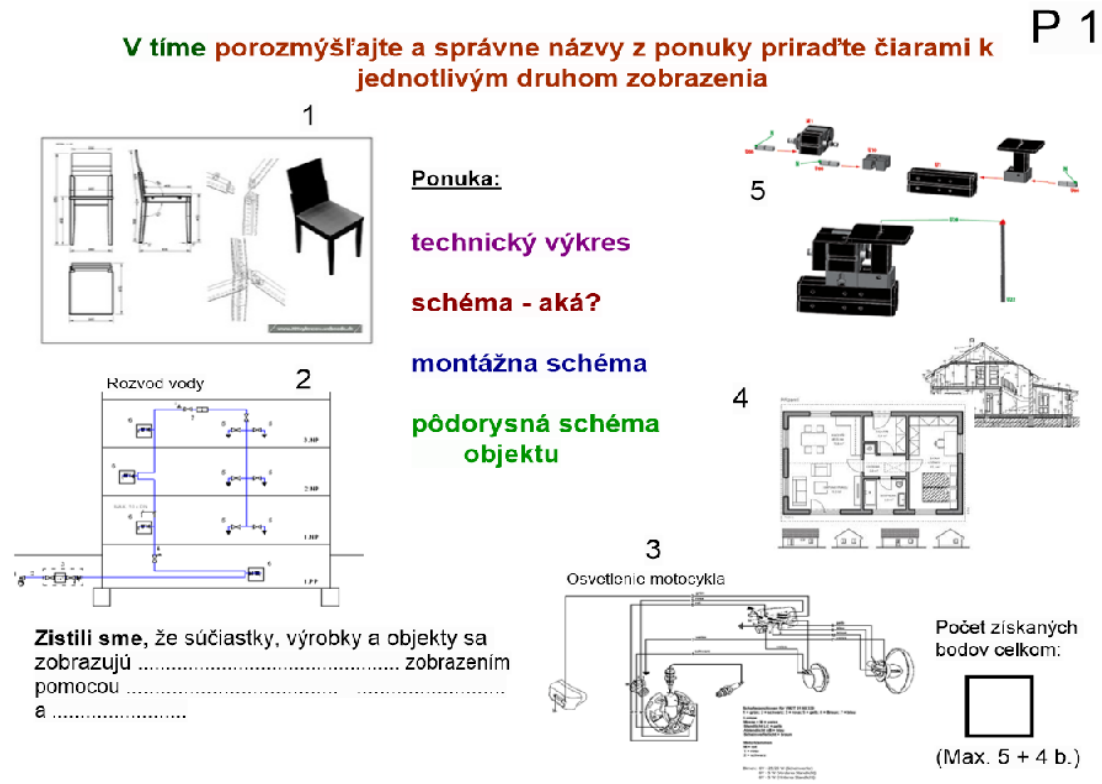

Obr. č. 1: Prvý pracovný list žiaka a zároveň stránka predvádzacieho zošita IT k téme vyučovacej hodiny Schematické značky, jednoduchý elektrický obvod. 


\section{Výsledky výskumu}

Nakol'ko v tomto príspevku vzhl'adom na rozsah výsledkov čiastkových výskumov tieto nie je možné uviest', v nasledujúcej časti uvedieme najmä celkové výsledky výskumu.

Tabul'ka 3 poskytuje sumárne informácie o tom, ktorí z členov výskumného tímu realizoval čiastkové výskumy, $v$ kol'kých $Z \breve{S}$, v ktorých ročníkoch ZŠ, kol'ko tém vyučovania bolo $\mathrm{v}$ rámci experimentálne výučby vo vybraných školách realizovaných a v ktorom učebnom predmete, vrátane počtov pozorovaných skupín žiakov.

\begin{tabular}{|c|c|c|c|}
\hline Riešitel' / pracovisko & $\begin{array}{l}\text { Počet } \mathrm{ZŠ} / \\
\text { ročník }\end{array}$ & $\begin{array}{l}\text { Téma vyučovacej } \\
\text { hodiny / učebný } \\
\text { predmet }\end{array}$ & $\begin{array}{l}\text { Počet } \\
\text { pozorovaných } \\
\text { skupín žiakov }\end{array}$ \\
\hline \multirow{2}{*}{ Pavelka / Prešov } & 3/ 8. a 9. roč. & Téma $1 / \mathrm{T}^{1}$ & 6 (12 žiakov) \\
\hline & 2/8. a 9. roč. & Téma 2 / T & 4 (8 žiakov) \\
\hline Šoltés / Prešov & 1/7. roč. & Téma 1 / T & 4 (8 žiakov) \\
\hline Litecká / Prešov & 3 / 5., 6. a 8 roč. & Téma $1 / \mathrm{T}$ & 6 (12 žiakov) \\
\hline \multirow{3}{*}{ Šterbáková / Prešov } & $1 / 7$ & Téma $1 / \mathrm{F}^{2}$ & 2 (4 žiaci) \\
\hline & 1/9. roč. & Téma 2 / F & 2 (4 žiaci) \\
\hline & 1/9. roč. & Téma 3 / F & 2 (4 žiaci) \\
\hline \multirow{2}{*}{ Brajerčík / Prešov } & $2 / 8$. roč. & Téma $1 / \mathrm{M}^{3}$ & 4 (8 žiakov) \\
\hline & $2 / 8$. roč. & Téma 2 / M & 4 (8 žiakov) \\
\hline \multirow{3}{*}{$\begin{array}{l}\text { Kozík, Brečka, } \\
\text { Valentová / Nitra }\end{array}$} & $\begin{array}{l}2 / 6 . / 2 \text { sk a } 8 . \\
\text { roč. }\end{array}$ & Téma 1 / T & 8 (16 žiakov) \\
\hline & 1 / 6. a 8. roč. & Téma 2 / T & 4 (8 žiakov) \\
\hline & $2 / 8$. roč. & Téma 3 / T & 4 (8 žiakov) \\
\hline \multirow{3}{*}{$\begin{array}{c}\text { Ďuriš, Bendík / Banská } \\
\text { Bystrica }\end{array}$} & 1/7. roč. & Témy 1 / T & 8 (16 žiakov) \\
\hline & 1/7. roč. & Témy 2 / T & 8 (16 žiakov) \\
\hline & $2 / 8$. roč. & Témy 3 / T & 32 (64 žiakov) \\
\hline Spolu: & 18 / 5. až 9. & 15 tém & 98 (196 žiakov) \\
\hline
\end{tabular}

$\mathrm{T}^{1}$ - technika, $\mathrm{F}^{2}$ - fyzika, $\mathrm{M}^{3}$ - matematika

\section{Tab. č. 3: Sumárne informácie o uskutočnených čiastkových výskumoch}

V zmysle výsledkov v tabul'ke 3 konštatujeme, že výskumný tím pozostával z 10 členov, čiastkové výskumy boli uskutočnené v 18 základných školách v ročníkoch 5. až 9 . Experimentálne bolo vyučovaných celkom 15 tém vyučovania, pričom z uvedeného počtu bolo 10 tém $(66,67 \%)$ z učebného predmetu technika, 3 témy $(20 \%)$ z fyziky a 2 témy $(13,33$ \%) z matematiky. V celkovom vyjadrení pozorovaniam počas vyučovacích hodín všetkých uvedených učebných predmetov bolo podrobených 98 dvojčlenných skupín žiakov, z toho 85,72 \% skupín žiakov v rámci hodín techniky, 6,12 \% skupín žiakov v rámci hodín fyziky 
a 8, 16 \% skupín žiakov v rámci hodín matematiky. Z hl’adiska ročníkov, v ktorých bola experimentálna výučba realizovaná, pozorovaní boli 4 žiaci 5. ročníka, 16 žiakov 6. ročníka, 66 žiakov 7. ročníka, 94 žiakov 8. ročníka a 16 žiakov 9. ročníka ZŠ.

\section{Diskusia a závery výskumu}

Ku komparácii, interpretácii a zhrnutiu celkových výsledkov výskumu zameraného na výskyt vybraných klúčových kompetencií žiakov sme pristúpili tak, že sme výsledky spracovali podl'a jednotlivých vybraných kategórií kl’účových kompetencií, k týmto prislúchajúcich vybraných klúčových kompetencií a ich výskytu podla výskumných subkolektívov a podla výskytu sledovaných javov v skupinách žiakov. Výsledky k uvedenému poskytuje tabul'ka 4.

\begin{tabular}{|c|c|c|c|c|c|c|c|}
\hline \multirow{3}{*}{$\begin{array}{c}\text { Kategória } \\
\text { kl'účovej } \\
\text { kompetencie }\end{array}$} & \multirow{3}{*}{$\begin{array}{c}\text { Vybraná } \\
\text { kl'účová } \\
\text { kompetencia }\end{array}$} & \multicolumn{5}{|c|}{ CELKOM } & \multirow{3}{*}{$\begin{array}{c}\begin{array}{c}\text { Zaradenie } \\
\text { úloh vo VŠ } \\
\text { učebnici }\end{array} \\
\begin{array}{c}\text { áno / nie / } \\
\text { odporúčame }\end{array}\end{array}$} \\
\hline & & \multirow[t]{2}{*}{$\begin{array}{c}\text { Pracovisko a } \\
\text { celkový } \\
\text { počet žiakov }\end{array}$} & \multicolumn{2}{|c|}{$\begin{array}{c}\text { Počet výskytov } \\
\text { javu }\end{array}$} & \multirow{2}{*}{$\begin{array}{c}\% \\
\text { áno }\end{array}$} & \multirow{2}{*}{$\begin{array}{c}\% \\
\text { nie }\end{array}$} & \\
\hline & & & áno & nie & & & \\
\hline $\begin{array}{l}\text { Interperso- } \\
\text { nálna }\end{array}$ & pracovat'v tíme & $\begin{array}{l}\text { Prešov } \\
\text { Nitra } \\
\text { B. Bystrica }\end{array}$ & $\begin{array}{c}36 \\
31 \\
118 \\
\end{array}$ & $\begin{array}{c}30 \\
1 \\
10\end{array}$ & & & áno \\
\hline \multirow[t]{2}{*}{ spolu } & & 226 & 185 & 41 & 81,86 & 18,14 & \\
\hline & $\begin{array}{l}\text { interpersonálne } \\
\text { vzt'ahy } \\
\text { harmonické }\end{array}$ & $\begin{array}{l}\text { Prešov } \\
\text { Nitra } \\
\text { B. Bystrica }\end{array}$ & $\begin{array}{c}57 \\
12 \\
118\end{array}$ & $\begin{array}{c}0 \\
20 \\
10\end{array}$ & & & áno \\
\hline \multirow[t]{2}{*}{ spolu } & & 217 & 187 & 30 & 86,18 & 13,82 & \\
\hline & $\begin{array}{l}\text { efektívne } \\
\text { pracovat' }\end{array}$ & $\begin{array}{l}\text { Prešov } \\
\text { Nitra } \\
\text { (technika) } \\
\text { B. Bystrica }\end{array}$ & $\begin{array}{c}- \\
18 \\
-\end{array}$ & $\begin{array}{l}- \\
14 \\
-\end{array}$ & & & áno \\
\hline \multirow[t]{2}{*}{ spolu } & & 32 & 18 & 14 & 56,25 & 43,75 & \\
\hline & $\begin{array}{l}\text { slovná } \\
\text { komunikácia, } \\
\text { sebaovládanie }\end{array}$ & $\begin{array}{l}\text { Prešov } \\
\text { (matematika) } \\
\text { Nitra } \\
\text { B. Bystrica } \\
\end{array}$ & $\begin{array}{l}3 \\
- \\
-\end{array}$ & $\begin{array}{l}0 \\
- \\
-\end{array}$ & & & odporúčame \\
\hline spolu & & 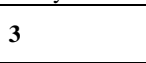 & 3 & $\mathbf{0}$ & $\begin{array}{c}100,0 \\
0\end{array}$ & 0,00 & \\
\hline Celkom & & 478 & 393 & 85 & 82,22 & 17,78 & \\
\hline Informačná & $\begin{array}{l}\text { informácie } \\
\text { kriticky } \\
\text { hodnotit' } \\
\text { a použit' na } \\
\text { riešenie } \\
\text { problému }\end{array}$ & $\begin{array}{l}\text { Prešov } \\
\text { Nitra } \\
\text { B. Bystrica }\end{array}$ & $\begin{array}{l}87 \\
- \\
-\end{array}$ & $\begin{array}{l}9 \\
- \\
-\end{array}$ & & & odporúčame \\
\hline \multirow[t]{2}{*}{ spolu } & & 96 & 87 & 9 & 90,62 & 9,38 & \\
\hline & $\begin{array}{l}\text { vyjadrovat' sa } \\
\text { graficky (napr. } \\
\text { nakreslit' } \\
\text { elektrickú } \\
\text { schému) }\end{array}$ & $\begin{array}{l}\text { Prešov } \\
\text { Nitra } \\
\text { B. Bystrica }\end{array}$ & $\begin{array}{c}40 \\
- \\
120\end{array}$ & $\begin{array}{l}12 \\
- \\
8\end{array}$ & & & áno \\
\hline spolu & & 180 & 160 & 20 & 88,89 & 11,11 & \\
\hline
\end{tabular}




\begin{tabular}{|c|c|c|c|c|c|c|c|}
\hline & $\begin{array}{l}\text { vyhl'adat' } \\
\text { informácie }\end{array}$ & $\begin{array}{l}\text { Prešov } \\
\text { (matematika) } \\
\text { Nitra } \\
\text { B. Bystrica }\end{array}$ & $\begin{array}{l}2 \\
- \\
-\end{array}$ & $\begin{array}{l}1 \\
- \\
-\end{array}$ & & & - \\
\hline spolu & & $\mathbf{3}$ & 2 & 1 & 66,67 & $\mathbf{3 3 , 3 3}$ & \\
\hline Celkom & & 279 & 249 & 30 & 89,25 & 10,75 & \\
\hline $\begin{array}{l}\text { Komunikač- } \\
\text { ná }\end{array}$ & $\begin{array}{l}\text { čítat's } \\
\text { porozumením }\end{array}$ & $\begin{array}{l}\text { Prešov } \\
\text { Nitra } \\
\text { B. Bystrica }\end{array}$ & $\begin{array}{c}77 \\
29 \\
- \\
\end{array}$ & $\begin{array}{c}23 \\
3 \\
- \\
\end{array}$ & & & áno \\
\hline \multirow[t]{2}{*}{ spolu } & & 132 & 106 & 26 & $\mathbf{8 0 , 3 0}$ & 19,70 & \\
\hline & $\begin{array}{l}\text { vyjadrovat'sa } \\
\text { ústne }\end{array}$ & $\begin{array}{l}\text { Prešov } \\
\text { Nitra } \\
\text { B. Bystrica }\end{array}$ & $\begin{array}{c}22 \\
18 \\
120 \\
\end{array}$ & $\begin{array}{c}20 \\
6 \\
8 \\
\end{array}$ & & & áno \\
\hline \multirow[t]{2}{*}{ spolu } & & 194 & 160 & 34 & 82,47 & $\mathbf{1 7 , 5 3}$ & \\
\hline & $\begin{array}{l}\text { vyjadrovat'sa } \\
\text { písomne }\end{array}$ & $\begin{array}{l}\text { Prešov } \\
\text { Nitra } \\
\text { B. Bystrica }\end{array}$ & $\begin{array}{c}\mathbf{5 7} \\
\mathbf{3 2} \\
\mathbf{1 2 0} \\
\end{array}$ & $\begin{array}{l}\mathbf{3} \\
\mathbf{0} \\
\mathbf{8} \\
\end{array}$ & & & odporúčame \\
\hline spolu & & 220 & 209 & 11 & 95,00 & 5,00 & \\
\hline Celkom & & 546 & 475 & 71 & 86,99 & 13,01 & \\
\hline Personálna & $\begin{array}{l}\text { kontrolovat' } \\
\text { svoje správanie }\end{array}$ & $\begin{array}{l}\text { Prešov } \\
\text { Nitra } \\
\text { B. Bystrica }\end{array}$ & $\begin{array}{c}27 \\
23 \\
104 \\
\end{array}$ & $\begin{array}{c}15 \\
9 \\
24 \\
\end{array}$ & & & áno \\
\hline \multirow[t]{2}{*}{ spolu } & & 202 & 154 & 48 & 76,24 & 23,76 & \\
\hline & $\begin{array}{l}\text { zodpovednost' } \\
\text { za výsledok }\end{array}$ & $\begin{array}{l}\text { Prešov } \\
\text { Nitra } \\
\text { B. Bystrica }\end{array}$ & $\begin{array}{c}26 \\
- \\
118 \\
\end{array}$ & $\begin{array}{c}8 \\
- \\
10 \\
\end{array}$ & & & áno \\
\hline \multirow[t]{2}{*}{ spolu } & & 162 & 144 & 18 & $\mathbf{8 8 , 8 9}$ & 11,11 & \\
\hline & $\begin{array}{l}\text { čestnost' } \\
\text { a zodpovednost' }\end{array}$ & $\begin{array}{l}\text { Prešov } \\
\text { Nitra } \\
\text { B. Bystrica }\end{array}$ & $\begin{array}{c}109 \\
23 \\
- \\
\end{array}$ & $\begin{array}{c}23 \\
9 \\
- \\
\end{array}$ & & & áno \\
\hline \multirow[t]{2}{*}{ spolu } & & 164 & 132 & 32 & 80,48 & 19,52 & \\
\hline & sebahodnotenie & $\begin{array}{l}\text { Prešov } \\
\text { Nitra } \\
\text { B. Bystrica }\end{array}$ & $\begin{array}{c}56 \\
- \\
- \\
\end{array}$ & $\begin{array}{c}24 \\
- \\
- \\
\end{array}$ & & & áno \\
\hline spolu & & 80 & 56 & 24 & $\mathbf{7 0 , 0 0}$ & 30,00 & \\
\hline Celkom & & 608 & 486 & 122 & 79,93 & 20,07 & \\
\hline Učebná & $\begin{array}{l}\text { motivovat' seba } \\
\text { aj druhých }\end{array}$ & $\begin{array}{l}\text { Prešov } \\
\text { Nitra } \\
\text { B. Bystrica }\end{array}$ & $\begin{array}{c}29 \\
18 \\
- \\
\end{array}$ & $\begin{array}{c}17 \\
6 \\
- \\
\end{array}$ & & & áno \\
\hline \multirow[t]{2}{*}{ spolu } & & 70 & 47 & 23 & 67,15 & 32,85 & \\
\hline & riešit' problém & $\begin{array}{l}\text { Prešov } \\
\text { Nitra } \\
\text { B. Bystrica }\end{array}$ & $\begin{array}{c}55 \\
31 \\
- \\
\end{array}$ & $\begin{array}{c}23 \\
1 \\
- \\
\end{array}$ & & & áno \\
\hline spolu & & 110 & 86 & 24 & 78,18 & 21,82 & \\
\hline Celkom: & & 180 & 133 & 47 & 73,89 & 26,11 & \\
\hline Kognitívna & $\begin{array}{l}\text { kritické } \\
\text { myslenie a } \\
\text { hodnotenie }\end{array}$ & $\begin{array}{l}\text { Prešov } \\
\text { Nitra } \\
\text { B. Bystrica }\end{array}$ & $\begin{array}{c}96 \\
31 \\
118 \\
\end{array}$ & $\begin{array}{c}52 \\
1 \\
10\end{array}$ & & & áno \\
\hline Celkom: & & 308 & 245 & 63 & 79,55 & 20,45 & \\
\hline
\end{tabular}

Tab. č. 4: Celkové výsledky výskumu so závermi na zaradenie úloh na rozvoj vybraných klúčových kompetencii žiakov do vysokoškolskej učebnice a do Modulu IT pre výučbu študentov VS̆ 
Hlavným dôvodom použitia elementárnej štatistiky pri vyhodnotení celkových i čiastkových výsledkov výskumu bola skutočnost', že výskumný tím nepovažoval zatial' za potrebné použit tie štatistické metódy, ktoré by poskytli dáta na ich híbkovú analýzu a ich štatistickú verifikáciu. To nebolo cielom a zámerom výskumu. Výskumný tím v reálnej školskej praxi realizoval prvotný výskum daného zamerania, ktorého hlavným ciel'om bolo skúmat' a overit', či vypracované a experimentálne overované stratégie a modely výučby $\mathrm{s}$ použitím IT a čebných pomôcok vytvárajú počas výučby predmetov $\mathrm{T}-\mathrm{F}-\mathrm{M}$ také podmienky, ktoré rozvíjajú vybrané klúčové kompetencie žiakov ZŠ. Potvrdenie uvedeného bolo pre výskumný tím nesmierne dôležité ako základné východisko na dosiahnutie hlavných ciel'ov, t.j. na vypracovanie vysokoškolskej učebnice a na zavedenie Modulu IT do výučby študentov s príslušným predmetovým zameraním na učitel'ských fakultách FHPV PU v Prešove, PF UKF v Nitre a FPV UMB v B. Bystrici. Výsledky uvedené v tabul'ke 4 je potrebné z hl'adiska celkového počtu žiakov a počtu výskytu javov vnímat' sumárne, čo znamená, že počet výskytov rovnakého javu sa zvyšoval pri pozorovaní toho istého žiaka v závislosti od počtu úloh, pri ktorých riešení sa sledovaný jav u žiaka mal vyskytnút', resp. sa vyskytol. Uvedené vysvetl'uje zdanlivý nesúlad medzi celkovými počtami žiakov, ktoré uvádzajú tabul'ky 3 a 4.

$\mathrm{Z}$ analýzy výsledkov kategórie interpersonálne kompetencie vyplýva, že zo skúmanej vzorky žiakov ZŚ pri riešení úloh prejavilo kompetenciu pracovat' v tíme $81,86 \%$ žiakov a u $18,14 \%$ žiakov sa táto kompetencia neprejavila napriek tomu, že zadanie úloh si spoluprácu v tíme vyžadovalo. Väčšina žiakov pozorovaných skupín (86,18 \%) prejavila kompetenciu pracovat' $v$ rámci harmonických interpersonálnych vzt’ahov. Aj napriek početnost'ou malým vzorkám pozorovaných žiakov konštatujeme, že temer u polovice žiakov (Nitra - technika $43,75 \%$ ) sa prejavila nízka miera v schopnosti efektívne pracovat' a 100,00 \% žiakov (Prešov - matematika) prejavilo kompetenciu slovne komunikovat' a sebaovládat' sa. Pri celkovom vyjadrení skúmaných kompetencií kategórie „interpersonálne“ predstavuje pomer „áno“ ku „nie“ $82,22 \%$ ku 17,78 \%. Uvedené značí, že v pozorovaných skupinách žiakov v najvyššom rozsahu $18,14 \%$ nie je na dostatočnej úrovni rozvinutá kompetencia pracovat' v tíme a v mierne nižšom rozsahu (13,82 \%), absentuje u žiakov kompetencia pracovat' v rámci harmonických interpersonálnych vzt'ahov. Absencia, resp. nerozvinutost' uvedených kompetencií u temer pätiny žiakov počas výučby je dôvodom na zaradenie príkladov použitého typu úloh $\mathrm{v}$ učebnici pre študentov a do výučby študentov.

$\mathrm{V}$ kategórii informačné kompetencie z analýzy výsledkov vyplýva, že zo skúmanej vzorky žiakov vo vysokej miere (90,62 \%) úlohami a d’alšími informačnými (vzdelávacími) zdrojmi poskytnuté informácie žiaci čítali a kriticky hodnotili. Při riešení úloh tieto žiaci vedeli použit' $v$ rozsahu $88,89 \%$, t.j. vyjadrovali sa graficky a v celkovom rozsahu 79,55\% žiaci kriticky mysleli, informácie hodnotili a pri riešení úloh použili. V celkovom vyjadrení skúmaných kompetencií kategórie „informačné“ predstavuje pomer „,áno“ ku „,nie“ 89,25 \% ku $10,75 \%$. Uvedené značí, že aj ked' v pozorovaných skupinách žiakov je na pomerne vysokej úrovni rozvinutá kompetencia vyjadrovat' sa graficky, temer u pätiny žiakov sa prejavil nedostatok v tom, že na základe kritického hodnotenia poskytnutých informácií žiaci nedokázali úlohy správne riešit'. Uvedené je dôvodom na zaradenie príkladov použitého typu úloh na rozvoj informačných kompetencií v učebnici a vo výučbe študentov. 
V kategórii komunikačné kompetencie výsledky ukazujú, že kompetenciou „,̌́itat' s porozumením“ disponuje 80,30 \% žiakov skúmanej vzorky, kompetenciou „vyjadrovat' sa ústne“ disponuje 82,47 \% žiakov a kompetenciou „vyjadrovat' sa písomne“ disponuje 95,00 \% žiakov. V celkovom vyjadrení 86,99 \% žiakov má na vysokej úrovni rozvinuté uvedené kompetencie, u 13,01 \% žiakov sa výskyt týchto zručností počas výučby neprejavil. Žiaci sú teda v skúmanej kategórii kompetencií v najvyššej miere schopní vyjadrovat' sa písomne $(95,00 \%)$, čast' žiakov $(17,53 \%)$ má problém s ústnym vyjadrovaním sa a temer pätia žiakov (19,70\%) informácie číta, ale týmto nerozumie a nevie ich pri riešení úloh použit'. Při komparácii $\mathrm{s}$ výsledkami, ako úspešne a správne žiaci úlohy riešili (kritické myslenie a hodnotenie informácií - pomer „áno“ $79,55 \%$ ku „nie“ $20,45 \%$ a riešit problém - pomer „áno“ $73,89 \%$ ku „nie“ $21,82 \%$ ), i ked’ pri celkovom vyjadrení skúmaných kompetencií kategórie „komunikačné“, kde predstavuje pomer „áno“ ku „nie“ 86,99 \% ku 13,01 \% prijímame záver, že v pozorovaných skupinách žiakov je počas výučby potrebné rozvíjat' vybrané kompetencie danej kategórie (najmä kompetencia čítat's porozumením a kompetencia vyjadrovat' sa ústne), čo je dôvodom na zaradenie príkladov použitého typu úloh v učebnici a vo výučbe študentov. Pri príprave d’alších úloh pre žiakov bude potrebné zvážit' aj rozvíjanie d'alších, pre prírodovedne a technicky orientované predmety, potrebných klúčových kompetencií, ako je napr. kompetencia argumentovat'.

$\mathrm{V}$ kategórii personálne kompetencie bol $\mathrm{v}$ rámci výskumu pozorovaný výskyt 4 subkategórii vybraných klúčových kompetencií žiakov. Výsledok týkajúci sa kompetencie „kontrolovat' svoje správanie“ (76,24 \%) je výraznejší v porovnaní s výsledkom v kompetencii „harmonické interpersonálne vzt’ahy“ (86,18\%) a výsledkom v kompetencie „pracovat' v tíme“ (81,86, \%), čo umožňuje prijat' záver, že v skúmaných vzorkách žiakov boli žiaci schopní pracovat' bez výraznejších rušivých momentov a teda disponujú uvedenými kompetenciami, aj ked' prejavy v nekontrolovaní svojho správania sa u žiakov boli početnejšie. Výsledky v ostatných troch skúmaných kompetenciách naznačujú, že vo vysokej miere $(88,89 \%$ ) žiaci disponujú kompetenciou ,zodpovednost' za výsledok“, temer u pätiny žiakov bol zaznamenaný výskyt negatívneho výsledku v kompetencii „čestnost' a zodpovednost" “ $(19,52 \%)$ a temer tretina žiakov $(30,00 \%)$ mala problém so sebahodnotením. Pri celkovom vyjadrení skúmaných kompetencií kategórie „personálne“, kde predstavuje pomer „áno“ ku „nie“ 79,93 \% ku 20,07 \% sme prijali záver, že $\mathrm{v}$ pozorovaných skupinách žiakov sa $\mathrm{v}$ priemernom vyjadrení prejavila nižšia úroveň rozvinutosti skúmaných kompetencií danej kategórie „kontrolovat' svoje správanie“, „čestnost' a zodpovednost"“ a ", sebahodnotenie“, čo je dôvodom na zaradenie príkladov použitého typu úloh v učebnici a vo výučbe študentov.

$\mathrm{Z}$ analýzy výsledkov kategórie učebné kompetencie vyplýva, že zo skúmanej vzorky žiakov pri riešení úloh prejavilo kompetenciu „motivovat' seba aj druhých“ 67,15 \% žiakov a ostatných 32,85\% žiakov touto kompetenciou nedisponovalo. Uvedené má súvislost' s výskytom kompetencie „vyjadrovat’ sa ústne“, kde výsledky ukazujú, že 17,53 \% žiakov nedisponovalo predmetnou kompetenciou. Nie vel'mi pozitívnym zistením $\mathrm{v}$ kategórii vybraných učebných kompetencií je výsledok v kompetencii „,riešit’ problém“, v rámci ktorej výskyt tejto kompetencie v „áno“ je 78,18 \% a viac ako pätiny žiakov „nie“ je 21,82 \%. Tento výsledok opätovne a v istej miere potvrdzuje aj výsledok v kategórii kognitívne kompetencie („nie“ - 20,45\%). V celkovom vyjadrení skúmaných kompetencií kategórie „učebné“, 
kde predstavuje pomer „áno“ ku „nie“ 73,89 \% ku 26,11 \% je záverom to, že vo viac ako u štvrtiny žiakov pozorovaných skupín nebol zaznamenaný výskyt rozvinutosti skúmaných kompetencií danej kategórie. Uvedené je dôvodom na zaradenie príkladov použitého typu úloh v učebnici a vo výučbe študentov.

Z analýzy výsledkov poslednej kategórie skúmaných vybraných kl’účových kompetencií - kognitívne kompetencie vyplýva že, kompetencia „kriticky mysliet’ a hodnotit““ (informácie poskytnuté žiakom v rámci jednotlivých úloh), sa v skúmaných vzorkách žiakov vyskytla v celkovom vyjadrení v rozsahu 79,55\%. Tento výsledok nie je zásadne negatívnym zistením, no v súvislosti s už vyššie interpretovanými výsledkami potvrdzuje, že pri vy̌ššj miere rozvíjania kompetencie „pracovat' v tíme“, „čítat' s porozumením“ a „riešit' problém“ vo výučbe, bolo by možné očakávat' aj vyššiu mieru rozvoja (i výskytu) skúmanej kompetencie. Pri celkovom vyjadrení kompetencie „kriticky mysliet' a hodnotit“", kde predstavuje pomer výskytu „áno“ ku „nie“ 79,55 \% ku 20,45 \% možno prijat’ záver, že při viac ako pätine žiakov pozorovaných skupín nebol zaznamenaný výskyt skúmanej kompetencie danej kategórie. Vzhl'adom na vysokú mieru potreby, aby žiak disponoval danou kompetenciou, považujeme za opodstatnené, aby príklady použitého typu úloh boli zaradené v učebnici a vo výučbe študentov.

Zistené výsledky, vzhl’adom na jednotlivé početnosti získaných vstupných i výstupných dát je možné len s vel'kou mierou opatrnosti podrobit' hlbším analýzam prostredníctvom štatistických postupov a programov s ciel’om verifikácie hypotézy výskumu a potvrdenia výsledkov do úrovne všeobecne platných pre základný súbor. Uvedené je v zámere výskumného tímu v d’alšom období. Pre členov výskumného tímu sú podstatnými tieto zistenia:

a) Navrhnuté modely a stratégie výučby aplikované vo výučbe učebných predmetov T F - M počas experimentálnej výučby vo vybraných ročníkoch 5. až 9 . ZŠ a vybraných témach vyučovacích hodín $\mathrm{v}$ spojení $\mathrm{s}$ využitím IT vytvárali podmienky a tým aj prispievali $\mathrm{k}$ rozvíjaniu vybraných klúčových kompetencií žiakov. Uvedené potvrdzuje súvislost' (závislost') vplyvu použitých učebných materiálov a stratégií s početnost'ou výskytu sledovaných javov (kompetencií) v celkovom priemernom pomere výskytu javov $81,91 \%$ ku $18,09 \%$.

b) Vypracovanie učebnice pre študentov techniky, fyziky a matematiky na učitel'ských fakultách a zavedenie Modulu IT do výučby je výsledkami čiastkových výskumov i celkovými výsledkami preukázané a opodstatnené.

Výsledky výskumu aj napriek menej početnej celkovej vzorke výskumu umožňujú o. i. vyslovit' aj tieto závery:

- celkové výsledky výskumných pozorovaní, ako aj vlastný proces výučby v experimentálnych triedach, potvrdili vhodnost' a správnost' navrhnutých, vypracovaných a na hodinách učebných predmetov T - F - M aplikovaných metodických materiálov a postupov,

- navrhnuté metodické materiály sú, v niektorých prípadoch, po vykonaní drobných úprav týkajúcich sa počtu úloh $\mathrm{v}$ pracovných listoch žiakov, $\mathrm{v}$ celom rozsahu použitel'né $\mathrm{k}$ d’alšiemu ich použitiu, t.j. k vypracovaniu vysokoškolskej učebnice so zameraním na IT a rozvoj vybraných klúčových kompetencií žiakov a zavedeniu Modulu IT 
do výučby študentov študujúcich učitel'ské študijné programy $\mathrm{s}$ príslušných predmetovým zameraním,

Osobitost' a novost' (netradičnost') navrhnutých a vypracovaných úloh pre žiakov, ktoré obsahovali modely výučby, predvádzacie zošity a pracovné listy žiakov v porovnaní s úlohami, ktoré učitelia žiakom bežne zadávajú deklarujeme nasledujúcim:

- úlohy pre žiakov umožnili skúmat' a vyhodnocovat' informácie o žiakoch v dvoch rovinách, t.j.:

a) vo výkonovej rovine - v kognitívnej a psychomotorickej oblasti (vedomosti, zručnosti a manuálne zručnosti - bodové hodnotenie úloh riešených žiakmi v PL, napr. dopisovanie údajov a slov, kreslenie elektrickej schémy atd'.). Podrobné údaje o vyhodnotení výkonov a zručností žiakov uvádza publikácia Pavelka - Kozík a kol. (2015).

b) v rovine osobnostnej (schopnosti a vybrané klúčcové kompetencie),

- novost' a netradičnost' úloh spočívala $\mathrm{v}$ tom, že úlohy boli konštruované tak, aby vytvárali priestor a zároveň vyžadovali od žiakov také aktivity a činnosti, ktoré doposial' žiaci počas výučby nerealizovali - teda rozvíjali vybrané klúčové kompetencie, napr. zaželat' spolužiakom úspechy v práci a motivovat' ich do práce, striedavo na riešení úloh pracovat' samostatne i spolupracovat' s partnerom v tíme v kl'udnej a priatel'skej pracovnej atmosfére, počas riešenia úloh samostatne i v tíme komunikovat' - vyjadrovat' sa ústne, písomne i graficky, počas riešenia úloh samostatne i v tíme kriticky hodnotit' a pracovat's informáciami (učivom) poskytnutými z rôznych informačných zdrojov (slovo učitel’a, text a obrázky v pracovnom liste a na IT, pomocný text, učebnica), čestne kontrolovat' (porovnat' správnost' riešenia úloh svojich aj partnerom riešených úloh so správnym riešením, ktoré na IT zobrazil učitel') a hodnotit' seba (pridelit' si body za správne riešenia úloh), žiaka pri tabuli (hodnotit' správnost' riešenia zakrúžkovaním „správne - nesprávne“) i tímového partnera (pridelit' body za správne riešenia úloh partnerovi) a body čestne a zodpovedne spočítat'.

$\mathrm{K}$ problémovým oblastiam, ktoré $\mathrm{z}$ našich výskumných aktivít vyplynuli a boli vypozorované počas výučby, vyplynuli z rozhovorov s učitel’mi zúčastnenými na výskume a ku ktorým sme dospeli na základe práce s výskumnými materiálmi patria:

- väčšina žiakov nemá skúsenosti a na dostatočnej úrovni rozvinuté zručnosti na prácu s IT,

- rozsah predvádzacieho zošita a rozsah pracovných listov pre žiakov (počet úloh) je v niektorých prípadoch potrebné čiastočne redukovat' vzhl'adom na dobu trvania vyučovacej hodiny (45 minút) a $\mathrm{v}$ závislosti od výkonovej úrovne žiakov, ich pracovného tempa, pritom náročnost' úloh je žiakom primeraná,

- proces kontroly a vyhodnocovania každej jednotlivej úlohy je pre výskumníka vel'mi náročný z hl'adiska pozornosti a zaznamenávania výsledkov jednotlivca a skupiny žiakov i celkového hodnotenia práce skupiny, ako aj z hladiska vysokej časovej náročnosti na spracovanie čiastkových a celkových výsledkov.

$\mathrm{K}$ niektorým našim zisteniam, ku ktorým sme dospeli na základe uskutočnených pozorovaní a ktoré nám $\mathrm{v}$ rámci rozhovorov učitelia potvrdili patria:

- žiaci dokážu pracovat' v skupinách, nie sú ale zvyknutí na vyššiu úroveň vzájomnej spolupráce, ako napr. v tíme vzájomne sa radit', čítat' odlišný text, vzájomne 
sa informovat' o jeho obsahu a vzájomne konzultovat' a „hl’adat"“ spoločné riešenie napr. úlohy, formulovat' záver a pod.,

- Žiaci zvyčajne školské úlohy riešia najradšej samostatne,

- žiaci nevedia, nie sú vedení k využívaniu možnosti efektívne v tíme spolupracovat', napr. rozdelit' si povinnosti pri riešení úlohy (napr. úlohu rozdelit' na dve časti, časti samostatne riešit', výsledok riešení v tíme sumarizovat', prijat' záver a tým ušetrit' čas na riešenie d’alších úloh),

- Žiaci majú problém vyjadrovat' sa ústne nielen pri neobvyklých úlohách a situáciách (hanbia sa vyjadrovat').

Spôsob vyučovania zameraného na ciel'avedomé rozvíjanie klúčových kompetencií žiakov vychádza predovšetkým z konštruktivistického prístupu. Takýto spôsob môže byt' prínosom pre modernizáciu prírodovedného vzdelávania a pre napíňanie koncepcie modernej školy. Našou snahou bolo navrhnút' zmeny vyučovania, v rámci ktorého žiak často prijíma informácie pasívne. Takéto vyučovanie sme sa pokúsili zmenit' tak, aby žiak bol aktívny a aby sa jeho kompetencie rozvíjali čo najefektívnejšie. Výsledkom by mala byt' kvalitatívna zmena vo vzdelávaní.

\section{Odporúčania pre pedagogickú prax}

Na základe zhrnutia celkových výsledkov výskumu odporúčame:

1. Ministerstvu školstva $V V$ a $\breve{S} S R$ - vypracovat', prijat' a v školskej praxi zaviest' systémový prístup $\mathrm{k}$ nákupu a vytvoreniu bezproblémového a kompatibilného využívania IT (vrátane k IT vytváraným učebným pomôckam) vo výučbe všetkých učebných predmetov ZŠ v rámci všetkých ZŠ v SR.

2. Vedeniam základných škôl:

- podporit' učitel'ov techniky a prírodovedných predmetov tým, aby pre výučbu mali $\mathrm{k}$ dispozícii IT inštalovanú $\mathrm{v}$ školských odborných predmetových učebniach,

- iniciovat školských správcov systémov IKT, aby priamo $\mathrm{v}$ školách vytvárali podmienky na univerzalizáciu softvérového vybavenia IT $\mathrm{s}$ ciel'om v školách vytvorit' podmienky na bezproblémové využívanie rôznych druhov IT vo výučbe v rámci danej školy.

3. Učitel'om techniky a prírodovedných predmetov $\vee Z \check{S}$ :

- vyvinút' aktivity zamerané na získanie IT a jej inštalovanie v odborných predmetových učebniach,

- vytvárat' vlastné modely a stratégie výučby, predvádzacie zošity a pracovné listy pre žiakov zamerané tak na zatraktívnenie a zefektívnenie výučby, ako aj na zavedenie zážitkového učenia sa a rozvoj klúčových kompetencií žiakov.

\section{Záver}

Skíbit' dve relatívne samostatné oblasti, ako sú klúčové kompetencie a interaktívne prostredie, ktoré sa $\mathrm{v}$ teoretickej rovine doposial' viac-menej vyvíjali samostatne, nie je jednoduchou záležitost'ou. Napriek tomu kolektív výskumníkov zameral svoju pozornost' na vytvorenie možného prieniku uvedených oblastí so zámerom prispiet’ nielen k zvýšeniu účinnosti výučby, ale pokúsit' sa zároveň vytvárat' vo výučbe podmienky na rozvoj klúčcových kompetencií žiakov. Výsledky výskumu ukázali, že vytvorené učebné materiály a navrhnuté 
metodiky v rámci experimentálnej výučby vhodné podmienky na rozvoj vybraných klúčových kompetencí žiakov nielen vytvárali ale k ich rozvoju aj prispievali.

\section{Literatúra}

Dostál, J. (2011). Reflections on the Use of Interactive Whiteboards in Instruction in International Context. The New Educational Review. Vol. 25. No. 3. p. $205-220$. ONLINE CZ.1.07/1.1.06/02.0092. [online]. [09. 08 2015]. Dostupné na: $<$ http://jtie.upol.cz/clanky/reflexe_vyuzivani_interaktivnich_tabuli_ve_vyuce_v_mezinarod nim_kontextu.pdf

Duriš, M. \& Pavelka, J. (2015). Implementácia interaktívnej tabule vo výučbe techniky, fyziky a matematiky v základnej škole. Prešov : Vydavatel'stvo Prešovskej univerzity.

Gavora, P. (1996). Výskumné metódy v pedagogike, Bratislava, Metodické centrum.

Gavora, P. (2008). Úvod do pedagogického výskumu. 4.vyd. Bratislava : Univerzita Komenského.

Gillen, J., Staarman, J. K., Littleton, K., Mercer, N. \& Twiner, A. (2007a). 'learning revolution'? Investigating pedagogic practice around interactive whiteboards in British primary classrooms "Learning, Media and Technology 32.

Hrmo, R., \& Turek, I. (2003). Klúčové kompetencie I. Bratislava: Slovenská technická univerzita.

Hyland, T. (1995). Competence, Knowledge and Education. In: Journal of Philosophy of Education, roč. 27, č. 1, s. 57-68.

Jeavons, A. C. (2005). Interactive Whiteboards: Developing a pedgogy for mathematics classroom. In JOHNSTON - WILDER, Sue; PIMM, David. Teaching secondary mathematics with ICT. Cornwall (Great Britain).

Kerlinger, F. N. (1972). Základy výskumu chování. Praha: Academia.

Lovász, T. (2014). Príprava materiálov pre interaktivnu tabulu, vzdelávanie pedagógov. [online] . [cit. 2016-04-02]. Dostupné na: http://www.interaktivnatrieda.sk/pripravamaterialov-pre-interaktivnu-tabulu-vzdelavanie-pedagogov/

Netky: Interaktívne tabule, notebooky či tablety dostane 3400 škôl. 2014. [online] . [cit. 2016-03-21]. Dostupné na:

http://www.netky.sk/clanok/interaktivne-tabule-notebooky-ci-tablety-dostane-3-400-skol Pavelka, J., \& Kozík, T. eds. (2015). Interaktívne prostredie a klúúcové kompetencie. 1. vyd., Prešov: Vydavatel'stvo Prešovskej univerzity. Sprievodný materiál: CD př́loha.

Švec, V. (1998). Kličové dovednosti ve vyučováni a vycviku. Brno: Masarykova univerzita. TASR (2014). Školy v týchto dňoch dostávajú tablety, interaktivne tabule či tlačiarne. [online] . [cit. 2016-03-25]. Dostupné na:

https://www.istp.sk/clanok/5500/Skoly-v-tychto-dnoch-dostavaju-tablety-interaktivnetabule-ci-tlaciarne

Turek, I., (1998). Učitel' a pedagogický výskum. Bratislava: Metodicko-pedagogické centrum. Turek, I., (2002). Klúčové kompetencie žiakov. In: Pedagogické rozhlady. č. 2, s. 3-7. 